\title{
How Many Countries?
}

\section{Stephen Muecke}

It's really a great honour for us, the authors of Reading the Country, that our book is the pretext for this festival. And I think I can speak for the other two in saying that we applaud your aim to 'revisit and recapture the intellectual radicalism and political energy of that time'. We certainly need it, and I could go on to talk gloomily of the dark times we live in. But capturing such times is partly what I am getting at with my title, 'How Many Countries?' I will go on to talk about multiple ontologies and other arcane matters under that heading, but my first point is that reading the country, reading any part of the nation, including Roebuck Plains, for me means sooner or later confronting the effects of globalising corporate capital.

Things may have seemed a little more innocent in 1983, when we slaked our thirst with the beautiful cold water of the spring at Djarrmanggunan, Paddy Roe's birthplace. The water was rushing out of a pipe into an old bath serving as a cattle trough. Paddy stood up and said of the water, 'Aaa yeah, middle of the heat more cold.' ${ }^{1}$ And today the spring has been trampled by cattle and no water is visible, only mud. It is not just cattle on Roebuck Plains destroying the jila (springs). The industrial regime is changing from pastoral to heavy industry. Exploratory fracking licences have been issued from near Broome right across to the Fitzroy river valley. Cultural and ecological issues are sidelined by what seems to be a massive neoliberal consensus (corporations plus the state plus most workers) about what is 'good' for the country. ' 'Country', then, is a word whose meaning can oscillate wildly between small sites and the whole nation. ${ }^{3}$ That's not a bad thing. Trick is to make that oscillation work for you, if you care for country, not just leave it in the hands of exploiters. I agree with myself then, my 1984 self, that it is important to keep even the smallest 
sites visible. And that even the smallest sites contain masses of knowledge, and perhaps power, a power of resurgence, if we refuse to accept that it is only a matter of time before the march of capital stamps its heavy footprint over the whole country, over many countries; that what happened in the Pilbara must now happen in the Kimberley, in the kind of logic the Western Australian Government uses.

There is more than one logic, just as there is more than one country, and it is with this pluralism that we can contest the narrative that 'it is only a matter of time'. 4 So, I'm going to tell you why, if I had to do it again, I could not write Reading the Country the same way. In fact, I am doing it again, with a book that might end up being called The Children's Country, about country up the coast to the north of Broome. Now, Reading the Country was composed around a fairly simple idea. Roebuck Plains was the one country, the constant, the pivot around which all these possible interpretations revolved. There was one country and multiple representations of it. For a long time now I have abandoned this subject-object model on the grounds that the country, like the European concept of Nature, would be made singular and foundational, and that the readings would be mere representations of it, historically real, but somewhat arbitrary, provisional and relative. Now, in a new model which I have learnt from Bruno Latour, I want to abandon the singular ground and give full ontological weight to each 'reading' or rather build up descriptions of several different worlds constituted by all kinds of things and beings, not just by humans who have the virtuoso capacity to see and read differently. ${ }^{5}$

So when Woodside Petroleum looks at Walmadany (James Price Point), the site on the coast that they wanted to use to build a gas plant and port, their activities institutionalise the site into a quite different world from the one that Paddy Roe showed me around decades ago, and different again from the one where the activists situate their base camp for the anti-gas campaign. What elements constitute the Woodside version of Walmadany? The resource they are after, methane gas, is central. They see it as a part of nature, over there, unconnected with us humans, in fact we are alienated from it. (I should add that popular ecological discourses share this same European 
view of Nature, which is why they too alienate humans from 'wilderness'). Woodside's modern institutions set up their outposts in this place such that certain practices can occur: an Economy, a way of doing Science and deploying technology, and a way of managing an organisation. A globalising western modernity extends its tentacles here as if it had no connection at all except to extract one part of its Nature, the gas, along the pipeline, which is now a metaphor as well as a technology, a metaphor for an institution that is built to get in and get out with nothing sticking to it. No need to renaturalise, as I like to say now.

Because if I no longer hold with one nature, and think there are many natures, one for each country, and that natures are entangled with cultures, then for me it follows that visitors have to renaturalise, to adapt after arrival. But you will protest: the laws of nature are universal, as shown by physics and chemistry. ${ }^{6}$ They are in a way, as if they were designed to permit another law, a law that powerfully exploits and transforms matter as if it came for free, in a world without end. Try telling the residents of the city of Baotou in Inner Mongolia that the mining of rare earths there comes for free. When these peoples' hair turns white and their teeth fall out, their bodies are making an argument that is specific to this particular natural-cultural arrangement. Universal laws of nature are not always relevant, they are specifically applicable.

Once you take the first step, establishing that nature has to be reinstituted, rebooted, because the version of nature that European modernity brought with it has hit an ecological wall, then the other institutions have to be readjusted as well. Science, the Law, the Economy, Aesthetics, all have to be reinstituted. They do not have to be completely replaced, because of course there are good things about them, and they have always, in any case, been subject to change. But with my new project, The Children's Country, I want to specify the changes that might have to be made in the light of indigenous and ecological local matters of concern. What will the children of the future think if we fail to start instituting the necessary changes? It is a question of survival, of persistence rather than opposition and critique. It is about redirecting the flow. For this reason, I want the book to speak, like Latour in his 
Inquiry, to each mode of existence (Science, the Law and so on) on its own terms, as they are practically instituted. The ethnography, the descriptive writing, will follow what it is that keeps the institutions alive as going concerns. These instituted modes are equally real as each other and are busily and simultaneously composing themselves, with and without our help. They are works in progress, and I hope to expose their more solid attributes as well as their sensitivities. Humans and things interact in the composition of these worlds, they intra-act agentially, as Karen Barad puts it, because this is a process in which human subjectivities are being invented and sustained. ${ }^{7}$ Likewise, in what we used to call the 'objective world', facts are brought into being and kept alive in their networks of relations. So-called Nature is no longer the privileged site of the real, nor is Society a place for humans alone.

\section{Surprising interruptions}

If the real is neither settled in some domain, nor separated off, it might be characterised, strangely enough, by surprise, or irruption. A bit like a scientist discovering something in their lab, yelling out and high-fiving their colleagues. Or a poet defamiliarising the most mundane object: 'So you think that because the rose/ is red that you shall have the mastery?'8 The real is present, emergent and performative. My ethnography will reproduce moments of surprise, encountered during 'field-work' which is kind of everywhere. It won't 'capture' those moments in a prose that reports back on them (across that interpretative divide) but reproduces the surprise with the necessary estrangement of its writing techniques.

I can illustrate this with a scene from Aaron Burton's documentary Sunset Ethnography (2014). I want to add, to the element of surprise or irruption that we are looking for in the scene, a suggestion to look for institutions. If we reject 'society', 'language' and 'nature' as too transcendent, we can nonetheless fall back on institutions, a very practical thing to do. When Mick Taussig, Teresa Roe and I 'act' in this film, whose institutions are we acting as extensions of? Or rather, how is our acting passionately extending those institutions?

For years I was in the habit of meeting the patriarch of the Goolarabooloo community, Paddy Roe, under the old 
tamarind tree where he had his meetings, and now, over a decade after he passed away, the tree is even more institutionalised. But I make a serious blunder as we are filming a documentary called Sunset Ethnography. Having decided that the tamarind tree might be a good spot to film a conversation, we install ourselves there as Aaron Burton is doing the filming. ${ }^{9}$ Michael Taussig and I are staging a conversation about the theory that is supposed to relate to the workshop on 'experimental ethnography' that we were holding at the time with a few colleagues in Broome:

Michael Taussig: What about a different understanding of the representation of theory itself in its relationship to, aah, call it raw life? That seems to be very important to me, that the theory is not like a ... flag that's nailed to the experiences, but has a much more ... sinuous relationship, often barely visible?

Stephen Muecke: Yeah, well, it does, I think. Like, from Michel Foucault I gleaned the idea of the, of the specific intellectual. And I found I could immediately say, yeah, well, that's what my friend Paddy Roe is. He's not a general intellectual, he's one that works through, um, specific situations, and his technique is a storytelling technique. He persuaded people. He did his politics through seduction, and ah... ${ }^{10}$

Local whitefella: G'day. The woman that owns this block is just inquiring as to what you're doing here.

SM: Teresa?

LW: Yeah, Teresa.

SM: Yeah, she knows me well. Tell her it's Steve.

LW: Steve, Steve's here. Is that all I need to say?

SM: I think so. 
READING THE COUNTRY: 30 YEARS ON

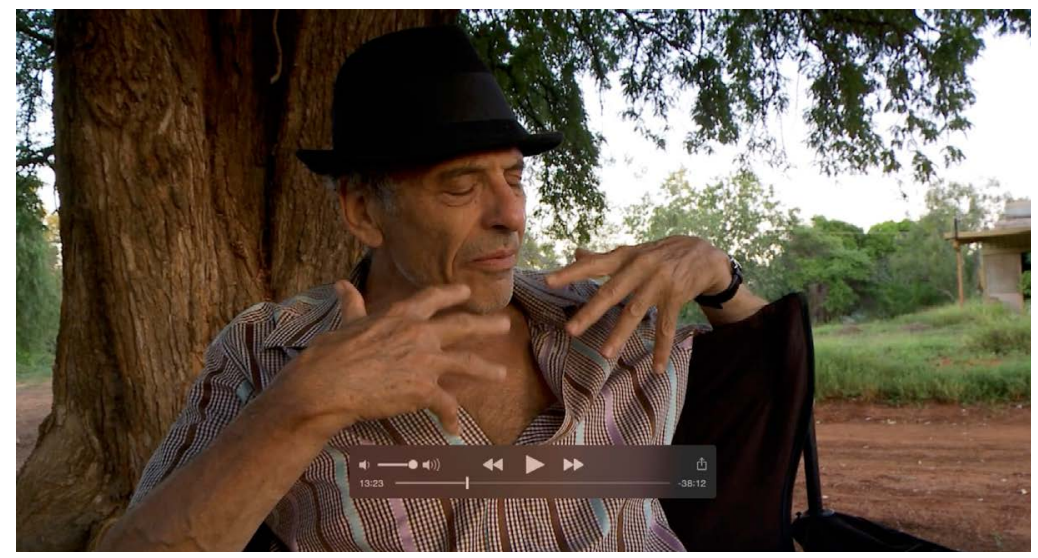

1.1 Mick Taussig, 2013

From Sunset Ethnography (C) Kurrajong Films, reproduced with permission

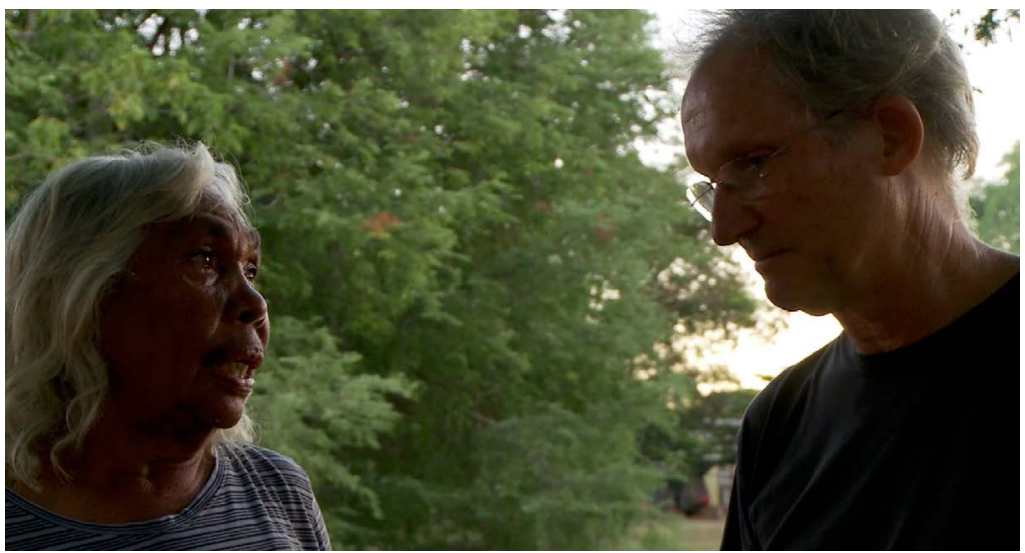

1.2 Teresa Roe with Stephen Muecke, 2013

From Sunset Ethnography (C) Kurrajong Films, reproduced with permission 
LW: Oh, she was a bit miffed. Somebody under the tree, she couldn't see who it was.

SM: Tell her I'm real sorry.

LW: I asked if they got permission, and she said, 'I don't know.'

SM: I didn't know I needed permission. I worked with old Lulu on this spot years ago, that's why I came back here.

LW: Yeah yeah, no, that's OK. No, nothing else needed?

SM: Tell her I'm sorry.

LW: Yeah yeah, that's all right $[$ He walks off $]$... Steve.

MT: What about the place of, ah, pictures and images in the story, that would seem to me to be important in developing the experimental ethnography?

SM: Yeah, well all I can think about them is their role as mediators. Um, they're not illustrations, they open another window, another mediation, so it's not about... 'I am interpreting the world', but er...

[Teresa Roe walks up]

MT: Hi there, how are you?

SM: How are you?

TR: Heeeey! Good to see you. Good to see you, Steve. [we hug] Been a long time.

SM: Yeah. Only last year I was here. [I introduce] My friend Mick.

MT: How you doing? 
SM: This is Aaron.

Aaron Burton: Nice to meet you. Hi.

SM: Well, we had some good news this week. ${ }^{11}$

So in order to be as practical as possible, as realistic as possible, I want to follow the networks of associations that keep institutions alive, especially as they encounter interruptions (like Taussig and I being interrupted in the smooth flow of our intellectual talk; or like when your ISP 'goes down' and you have to launch 'Network Diagnostics' software to find where in the chain of links the break is). With interruptions you find out once again how things work; the networks are made real again because we have to retrace the connections.

\section{Law and Dreaming}

Now let's take the institution of the (European) law in Australia, clearly a massive institution of statutes, courts and archives, closely networked with training institutions, legislative functions of government, enforcement functions of the police and so on. In its encounter with Aboriginal Australia we witness, historically and in the present, all sorts of 'interruptions' and failures. These are of interest to the ethnographer because they show the workings of this institution as it tries to repair the breakdowns. But why did they occur? Partly because there is another institution of the law, that Aboriginal people follow, called bugarrigarra around Broome. There are contradictions between White and Black laws, problems that are not solved by direct application of English Common Law. No, it has to be modified, things have to take time to go in a roundabout way; they zigzag, and after years of labour something called Native Title Law has been painstakingly produced in order to make compromises for an initial blunder of colonisation, the so-called Terra Nullius doctrine.

So if you are a White lawyer, you know how to inhabit 'the world of the law', with its networked institutions, actors and modes of existence. You may have no idea about what 
goes on in the institutions of Indigenous law, like the bugarrigarra. And if you are an anthropologist you might mediate, and get caught in the fight, as described by Paul Burke. He begins his Law's Anthropology: From Ethnography to Expert Testimony in Native Title, with an image of physical damage sustained by anthropologists in such encounters:

The bodies of anthropologists, bruised from their encounter with native title, are to be found recuperating all around Australia. Some, still wounded from humiliating cross-examination, swear, yet again, never to be involved in another native title claim. While they lament their lack of influence, others warn of native title completely engulfing anthropology and ruining it (see, for example, Morris 2004). One Aboriginal leader has made the opposite claim - that anthropology has engulfed native title law-blaming anthropology for the High Court's poor legal conceptualisation of native title. ${ }^{12}$

What causes these bruises on the bodies of anthropologists? It is not so much the mismatch between two different legal institutions, I think, it is the mismatch among three things: what is a stake for the Indigenous people (what they want to protect and sustain); the social-scientific methods of the anthropologists (with their specific modes of verification and authorisation); and the admissibility of evidence according to legal procedures and rulings. Three different regimes of truth that can inhabit the same space only with difficulty, the usual difficulties that are negotiated in the ins and outs of discussion in hearings, briefings, affidavits and last-minute promptings in the corridor.

Now, the anthropologists wouldn't have so many bruises if they could just work on so-called traditional cultures in a traditional way. They wouldn't have to test their science in public or in a law court to see if it holds up in another institution. At this point I could do a description of what I think bugarrigarra law is all about: the travelling of the ancestor beings Malara and $\mathrm{X}$ (who can't be named), the ceremonial procedures for the initiation of boys, the texts of the sacred songs, the ceremonial artefacts, and so on. Such descriptions of Dreamings 
often appear in anthropological texts on Australia, and they strike me as very partial translated summaries, struggling not to reproduce clichés. How can such law be given its full ontological weight? Perhaps it can't be in a text of a few pages, perhaps the text should somehow acknowledge the thousands of years it took for such a mode of existence to put on weight, for its existence to be really palpable? I don't think the ethnographer should give up in the face of this huge difficulty. On the contrary, one should try harder to write such a description, recognising the failures of past descriptions, looking to invent a new template that does it justice. ${ }^{13}$ It means, obviously, guarding against the age-old slogan of the front line of modernisation: 'they believe, we know'. When whitefella law makes a blunder, like 'Aborigines have no sovereignty over land', or when Western Australia's premier Colin Barnett, makes a political blunder like saying the coastline at walmadany is 'unremarkable', or an anthropologist makes a knowledge blunder like assuming Aborigines don't understand biological conception (because 'they believe' in rayi, children's spirits), then these failures call for new templates to be made. These modernists could try to carry on regardless, as they have in many cases, by forcing people off their homelands, or sending Aborigines to sex education classes so they can understand reproduction the correct scientific way. We have an inkling what is lost each time these modernist universalist templates are imposed without modification; a whole world is threatened, a whole world, not an Indigenous version of the same world.

Now, in conclusion, about the law, I want to worry about how these two laws relate to each other. I might have seemed to be saying that they were locked in battle, or ontologically incompatible; if one is in place, the other can't be. But if we listen to my teacher, Paddy Roe, he doesn't seem to say anything like that. $\mathrm{He}$ is talking more like a sovereign leader making a highly diplomatic statement:

Law-

That's bugarrigarra, law-

I think English say'dreamtime'- 
But we say bugarrigarralaw

He actually isn't opposing the two kinds of law. There is a different discursive logic here, the one that has been called 'same

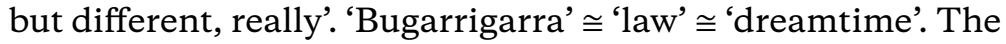
effect of the way that Paddy puts it is not contrastive at all, it is integrative of the things that actually are living there in the country, one next to the other. His style introduces a tonality, a smooth texture, a flow that invites you into its movement. Living country, they call it, or living culture. Paddy Roe's finger inscribes bugarrigarra into the sand at walmadany, as he is saying 'this is bugarrigarra'. He used to do it over and over, whenever some whitefella developer came along wanting to 'modernise' his country. As he inscribes bugarrigarra into the country, it is like saying, with an indexical sign that is not a sign, 'it is going to be very hard for you blokes to move us off here'.

\section{Reference and science}

Scientific knowledge, in Latour's account, is elaborated with a mode of existence he calls reference. ${ }^{14} \mathrm{It}$ is what enables knowledge to be passed and maintained across great distances in time and space. It might be born in labs and accumulate in archives, but it needs the collaboration of colleagues, human and non-human actors, to sustain it. It, too, is tested against alterity. This would be experimental method. If the same results can be obtained with a repetition of the experiment in a somewhat new context, then the facts are sustained and can continue to exist.

Now, Aboriginal people in Broome don't do this sort of thing, surely not? Where are their labs and archives? Exactly: while everyone agrees that Aboriginal people have lots of knowledge, they are not quite sure where they are hiding it. It kind of pops up unexpectedly. Let us recall, before going on to a case study, that Latour's 'Anthropology of the Moderns'15 has successfully 'provincialised' western modernism (as Chakrabarty led the way for history). The universalist pretentions of this modernity are now somewhat specified and moderated, and can only now enter into negotiations with all 
kinds of others. The old colonial pedagogical attitude, based on universalist pretentions, was not conducive to negotiation.

So the case of Phillip Roe and the sea turtles is relevant here. Phillip Roe is a key figure in the campaign against mining interests taking over the country that his family has custodianship rights over. Now, at the time of the Woodside Petroleum push to build a gas plant at Walmadany a team of scientists was engaged by the state government to carry out an environmental survey. Hawksbill and Green sea turtles were two animal species on the list to be investigated. The nesting study commissioned for the Department of State Development found only one 'old' nest and three false crawls. An independent and peer-reviewed study into marine turtle nesting in the James Price Point area led by University of Melbourne marine biologist Malcolm Lindsay found 14 turtle nests and 38 false crawls over the 2011/2012 nesting season. This independent study was one of a few carried out by 'citizen scientists' on different species. They were able to point out flaws in the design of the government report, which, for instance 'surveyed only $12 \%$ of the coastline most threatened by the precinct, overlooking the significant $6 \mathrm{~km}$. strip of important nesting habitat'. ${ }^{16}$

The scientists doing the government report didn't seek or obtain the help of Phillip Roe who has hunted turtles and gathered turtle eggs in season all his life. His people have been doing this for innumerable generations. He pointed out to the citizen scientists that turtles around Walmadany often nested on the rocky foreshore. The government scientist hadn't bothered to look there because they 'didn't expect' or 'would be surprised' to find turtles nesting in a rocky place. Informants were also amazed at Philip's uncanny ability to point out nests when they couldn't see any traces of a nest in the sand, or, on one occasion, pointing into the ocean and saying the special word (undud) for mating turtles. It took my informant a few minutes to see what Philip was seeing.

Alterity introduces the unexpected, disrupting the repetition of the already known that I think characterises the spread of modernist universals. For the government scientists the science hadn't really extended beyond the lab back in the city and they were closed to the possibility of extending collegiality 
to Phillip Roe. That the citizen scientists were prepared to do this meant that their lab included aspects of the West Kimberley. It went further in time and space, which is what a referential mode of existence is meant to do, as it discovers and then sustains its forms of truth so that they can be relied upon. ${ }^{17}$ This is what I mean by the process of renaturalisation, and it is what any good scientist would do anyway, that is, not expect that a new context will allow the reproduction of results from elsewhere.

\section{Politics in circles}

Surprise or discovery is not really what one expects from the mode of existence that is politics. Its truth conditions are not about extending knowledge in time and space, which is why we often accuse politicians of lying - they will renege on their pre-election promises. Politics is about extending representation, in both senses of the word; the politician counts for the people in the electorate, and hopes to speak to them and for them in a language in which they can recognise themselves. There would always be some difficulty for a white politician from a capital city far to the south to represent Aboriginal people who may even refuse to vote; but that is a rather general issue.

The more significant thing for my ethnography is the organisation of alliances that either builds up or diminishes the number of spheres of influence that are associated, broadly, with the two sides of the gas plant issue. And if I do not want to use 'society', I can replace it with 'association', which means not just associations of humans, but also things, concepts, feelings as these link up to create real worlds. 'Society' is what still has to be made, it is not the explanatory term one can easily fall back on.

The interiority of a sphere is constituted by the elements inside breathing the same atmosphere-you can tell that I'm using the language of Peter Sloterdijk here ${ }^{18}$ - or having the same values, while being surrounded by a membrane that provides immunity. To this, I would add Latour's idea of partnerships or allies in political causes, and different spheres might be drawn together in political association. Yet, these spheres are fragile, and tactics of imitation (Gabriel Tarde) 
are political tactics that attempt to redraw the spatial map of associations of different spheres. ${ }^{19}$ That the bubble of capitalist confidence is constantly under threat of bursting may not be such an arbitrary metaphor, and it certainly applies in the case of Woodside's tenuous relationship with its joint venture partners. Woodside's bubble finally burst in April 2013 when it announced that it would not continue with the 45 billion dollar gas plant. All along, it was the state government's financial and political support that was urging Woodside on. The head of government, Barnett, you might recall, was the one I said made a 'political blunder' in saying that the coastline at Walmadany was 'unremarkable'. Suddenly he wasn't talking the same language as the people he was supposed to represent. For them, the beautiful red cliffs were quite remarkable, which is where a political mode of existence can cross with an aesthetic one.

But just to conclude this section on politics; you will excuse me, I hope, for complicating the picture with the addition of Sloterdijk's spheres. But they are useful in that they reinforce Latour's rhetorical figure of the circle as that which characterises the political mode of existence. Politicians talk in circles. They can't be expected to adhere to the truth conditions of scientists whose knowledge is organised to persist over long distances and times. Political talk is true for short periods - as they say, 'a week is a long time in politics'. It sounds the right note, gathers further allies, and increases its sphere of influence. It will network with institutions and influential individuals to extend its circle, which of course was the case with Barnett's political work in the Kimberley, where the Aboriginal organisation the Kimberley Land Council was a key ally. In the end, Barnett's Woodside episode was a failure. In the state election of June 2013, a Green candidate collected 38 per cent of the votes in the town of Broome, going against the major parties' trends, and nearly getting elected.

\section{Aesthetics}

Now, if Barnett blundered politically by saying that the coastline was 'unremarkable' implying 'empty' in that timehonoured settler style, suitable for 'development', then this is a point where the aesthetic crosses the political. The red 
cliffs are identified with the places where people love to go fishing and swimming, which are significant sites for law and culture, which contribute to tourism - nothing much to do with capitalist efficiency, profitability and rationality (Latour). But feelings like 'love of country' cannot be ignored if my ethnography is to find out what the core values of the negotiating parties are. You know what the central values are when people will lay down their life for them. The late Joseph Roe said the last thing he would give up in any negotiation is the right to protect law and culture, bugarrigarra: he was like a garbina, shielding his country. While his major opponent, the politician Barnett, might say that the last thing he will give up is the right to exploit Nature, which probably comes down to Efficiency, Profitability and Objectivity, core values that never seem to migrate into Indigenous Australians' spheres of influence without threatening their very existence as Indigenous people.

I want to give an example of how this love of country was mobilised as political activism in the campaign against the gas plant, and stay within Sloterdijk's 'sphereology': spheres are interiorities that are defined by their passage to the outside through mechanisms of attraction, repulsion and flow. Sunday 13 May 2012 in Broome, Mothers' Day ${ }^{20}$, provided an 'atmosphere' in which the anti-gas protesters tried the charm of love hearts, and so on, to lure the police into imitative association and hence into a mutual sphere of protection. The protesters, against all expectations that there would be sporadic violent protests, came up with an unexpected idea. They tried to create a common sphere with the police; they could not assume they were already securely in one (as co-citizens of the Nation, for instance). This was a kind of spell exercised in the context of (what Latour used to call 'transfearance', now Metamorphosis) remembered as the previous year's 'Black Tuesday' when police got quite violent. The rhetoric of this 'Platonic love story' seemed to say: 'We are all within the charmed circle of mother-love-fertility, within yet another sphere of celebration of the national day for mothers.' All this is spatially organised and imitative rather than communicative - they would like the love to be contagious by association. 
This unexpected manoeuvre by the activist campaigners worked. It came as a surprise as it produced a counter-real. Some of the police said they were touched and took flowers home to their mums, the broader community was 'charmed' and therefore seduced into sympathy for the campaign. It was coherent with their core beliefs (What do you love about Broome? The beach, the fishing, Where do you go fishing? Up the coast...). Affect and other aspects of an aesthetic mode of existence take on weight here and assert their singular effects. They are strong in themselves, they are not the effect of something else. I have made the point about Barnett's mistake in trying to reduce this mode of existence. By saying 'unremarkable' he tried to deflate the aesthetic sphere, so that efficiency and profitability could take over. But by discounting the attachments of the Broome folk who 'love the place', he committed the basic political sin. He lost numbers. People moved and attached themselves to the 'Save Broome' campaign, which was contingently making itself attractive with the good timing of the Mother's Day event.

And let's not forget what is positively asserted by aesthetics for the Goolarabooloo and for the Broome people. The latter, and the tourists, even though they often make the mistake of equating 'country' with Nature, as in 'landscape', nevertheless inflate an aesthetic sphere with a million amateur and professional photographic clichés and postcards. That in itself is a long modernist European tradition. Let's not be too cynical, the aesthetic does come into existence each time a photo is taken; a way of being in the world is created ('instaured') as into each photo flows a formal composition that 'holds up'-as the photographer contemplates it on the screen and makes a decision to press the delete button or add it to the disparate archive that is helping keep an aesthetic associated with Broome alive.

An important aspect of Sloterdijk's sphereology is that he asks us to 'abandon the idea of space as an empty field'. ${ }^{21}$ Like Latour, who wants to trace real chains of association and transformation, Sloterdijk does not invest the gap or the 'in-between' with utopian potential. Spheres, as I am trying to imagine them, must abut like living cells in a body. Applied to James Price Point, Walmadany, we can now see this as a space that is 
full of Indigenous and activist/resistance tactics for togetherness; it is not an empty space for Woodside to occupy. Living in a sphere is a vital experience of being animated together; the same experience applies to media spaces like Facebook as used by the Save the Kimberley and other allied groups.

This spatial tightness, with spheres abutting each other and sometimes dissolving into each other when they find they are swimming in the same atmospheres, breathing the same oxygen, also means that discourses of emancipation don't work so well for the analysis and the writing we might perform. It will not be a question henceforth of cutting ties in order to liberate, but cutting ties in order to engineer further and more productive connections; changing the flow. This has consequences for the writing of ethnographies which work up close with their partners in a critical proximity (immersion) characteristic of forms of fictocriticism, like that of Kathleen Stewart. ${ }^{22}$ Critical proximity means not withdrawing to a 'perspective' out in that empty space somewhere, that claims overview and impartial judgement. It means a contingent and negotiated 'earning the right to participation' in a particular sphere, as I have said elsewhere. ${ }^{23}$

So, I'll be interested to hear what you think about my new version of Reading the Country as applied to an ethnography of the country north of Broome. As I said, I can no longer hold the 'country' as central and equivalent to Nature or the objective world. Nature has to be rebooted, reinstitutionalised through a process of renaturalisation. This recasting of Nature, so that it becomes closer to natural-cultural compositions, is closer to Indigenous networking, I think, where bilbies, turtles and whales are all part of 'society' and play their parts as enshrined in the Law.

So once Nature is rebooted, all the other modes of existence have to be adjusted too. ${ }^{24}$ The scientist arriving to do an EPA realises that her European version of Nature - one size fits all-will not cut it. By paying 'due attention' (Whitehead) she will be surprised by the 'something more' that is offered by the processes of natures reproducing themselves. Methodologies might have to be adjusted too. Scientific reliability comes through spreadsheets and statistics, and that is essential. But to them she might have to add Indigenous 
colleagues with their non-statistical ways of knowing. They also perform exactly what scientific modes of knowledge are supposed to do-make knowledge persist through the generations and across great distances. I want the sciences to be able to do what they do best, but in a new way adjusted to local conditions. For example, Steven Salisbury, the paleontologist of the dinosaur footprints, collaborates in a way that makes him an exemplary kind of scientist in the way I have been describing. He is prepared to say, working with Richard Hunter, that a dinosaur footprint is the emu marala, not 'they believe' it is marala, while 'we know' it is really a trace of a 130-million-year-old suaropod. ${ }^{25}$

And in a multirealist framework, each mode of existence has its own way of reproducing itself, with its own felicity conditions. They can be described in such a way that they don't try to take over each others' territory, either crossculturally, or within a given 'culture'. There are good reasons why English common law can't take over the bugarrigarra, reduce it to some sub-clauses covering 'customary law'. There are good reasons why, within what many whitefellas like to call their 'modern society', the Economy can't take over the institutions of the Law, or Science swallow up the Aesthetic, or Politics trump Religion.

Where, you might ask, is the political edge in all this happy pluralism? As the planet faces up to what could be its greatest set of crises, radically new conditions will pertain. We can either ecologise and adjust, or continue to modernise as usual. Those who would do the latter know that the planet can't sustain that strategy, yet they are prepared to go for the end-game. In the name of 'what the market can stand', they attack every progressive institution within sight. For me, the politics of caring for country, for countries, for the whole country, is one of caring for the institutions that sustain what we care most about: scientific discoveries, creating works of art, organising politically to increase numbers. I think it is a mistake to start from the position of 'protecting Nature' via country. Nature as the stable backdrop to human activity is an idea as dangerous to human existence, as the notion of the Economy as second nature is toxic. Nature is composing itself in conjunction with our institutions, through multiple mediations. The sea grass 
of Roebuck Bay maintains its existence with the care of the working group from Environs Kimberley. This is a mediation the Goolarabooloo and the other Indigenous peoples of the country have always understood, life sustained by networks of multiple beings. Avoiding the reduction to Nature means also taking seriously and helping grow their precarious institutions, like Paddy Roe's tamarind tree in Broome, that have already provided answers to really important questions like, how do you look after country without money, without Native Title and without a Nature-Culture divide?

\section{Notes}

1 Kim Benterrak, Stephen Muecke and Paddy Roe, Reading the Country, 3rd edn, Re.Press, Melbourne, 2014, p. 48.

2 David Trigger, 'Mining, Landscape and the Culture of Development Ideology in Australia', Ecumene, no. 4, 1997, pp. 161-8o.

3 The term 'Country' has been increasingly used over the last few years for some Indigenous version of the home territory for which one is a TO (traditional owner), for instance 'buru' in the West Kimberley. It is especially evident in the phrase 'being on Country', which implies a reciprocal ethics of care.

4 Isabelle Stengers, 'Introductory Notes on an Ecology of Practices', Cultural Studies Review, vol. 11, no.1, March 2005, pp. 183-96.

5 Bruno Latour, An Inquiry into Modes of Existence: An Anthropology of the Moderns, Harvard University Press, Cambridge, MA, 2013.

6 'The globalization of knowledge is clearly not a one-way process of intended transmission ... in modern science, knowledge becomes global both by processes of localization and delocalization. Knowledge is always bound to local conditions of its reproduction, and the problem of encounters between different knowledge systems embedded in different local conditions is a persistent feature of historical development.' Jürgen Renn and Malcolm D. Hyman, 'Chapter 24: Survey', in Jürgen Renn (ed.), The Globalization of Modern Science, Edition Open Access, Berlin, 2012, p. 563. http://edition-open-access.de/studies/1/28/index.html Karen Barad, 'Posthumanist Performativity: Toward an Understanding of How Matter Comes to Matter', Signs, vol. 28, no. 3, Spring 2003, pp. 801-31.

8 William Carlos Williams, Paterson, Book I, New York, New Directions Publishing, 1995, p. 29.

9 Sunset Ethnography, dir. Aaron Burton, 2014. https://vimeo.com/113130961

10 See 'Intellectuals, Power and Truth,' in Benterrak, Muecke and Roe, pp. 168-75.

11 Sunset Ethnography, 12'.48' to 18'.0o'

12 Paul Burke, Law's Anthropology: From Ethnography to Expert Testimony in Native title, referring to Noel Pearson in the Age, 28 August 2002.

13 Latour AIME website: 'The first question is modernisationist; a front line of modernisation is set up which is going to limit, each time it is extended, the range of available types that could explain any situation. The second solution consists in doing the analysis of this modernisation effort by noting, on each possible occasion, the failures of the first solution.' http://www.kachinas.be/seminairelatour/wp-content/uploads/sites/2/How-To-AIME.pdf

Latour, Inquiry, chapter 3. 
15 Latour, Inquiry.

16 Environs Kimberley media release, 30 March 2011. http://www.environskimberley. org.au/wp-content/uploads/2012/02/EKMR-3003121.pdf

17 The Wilderness Society, Environs Kimberley and Conservation Council of WA, James Price Point Science Assessment Report: Updated Supplementary submission on the WA government's Browse LNG Strategic Assessment for a proposed gas processing hub at James Price Point, Kimberley WA, May 2012.

http://www.environskimberley.org.au/wp-content/uploads/2015/11/james-pricepoint-science-assessment-report.pdf

18 Peter Sloterdijk, Bubbles: Spheres Volume I: Microspherology, trans. Wieland Hoban, Semiotext(e), Los Angeles, 2011.

19 Gabrielle Tarde, Les lois de l'imitation, Félix Alcan, Editions Kimé, Paris, 1993 [1890].

20 Stephen Muecke, The Mother's Day Protest and other Fictocritical Essays, Rowman and Littlefield International, London 2016, chapter 2.

21 Réné ten Bos and Kaulingfreks, 'Interfaces', Theory, Culture $\mathcal{E}$ Society, vol. 19, no. 3, 2002, pp. 139-51, p. 142.

22 Kathleen Stewart, Ordinary Affects, Duke University Press, Durham, 2007.

23 Stephen Muecke and Max Pam, Contingency in Madagascar, Intellect Books, Bristol, 2012, p. 19.

24 Didier Debaise, Pablo Jensen, M. Pierre Montebello, Nicolas Prignot, Isabelle Stengers and Aline Wiame, 'Reinstituting Nature: A Latourian Workshop', trans. Stephen Muecke, Environmental Humanities, vol. 6, no. 1, 2015, pp. 167-74. http://environmentalhumanities.dukejournals.org/content/6/1.toc

25 University of Queensland Dinosaur Lab. http://www.uq.edu.au/dinosaurs/index. html?page $=157055$ 